\title{
BIOACTIVE COMPOUNDS IN BENGKOANG (Pachyrhizus erosus) AS ANTIOXIDANT AND TYROSINASE INHIBITING AGENTS
}

\author{
Endang Lukitaningsih ${ }^{1 *}$, Ulrike Holzgrabe ${ }^{2}$
}

\author{
1Dept. of Pharmaceutical \\ Chemistry, Faculty of \\ Pharmacy, Gadjah Mada \\ University, Sekip Utara, \\ Bulaksumur, \\ Yogyakarta 55281, Indonesia \\ 2Dept of Pharmacy and \\ Food Chemistry, Würzburg \\ University, Am Hubland, \\ 97074, Würzburg, Germany
}

Submitted: 11-11-2013

Revised: $10-01-2014$

Accepted: 15-03-2014

*Corresponding author Endang Lukitaningsih

Email :

lukitaningsih_end@yahoo.com

\section{INTRODUCTION}

Bengkoang is a species of Pachyrizus and grows naturally in many tropical and subtropical countries such as America and Asia. It is usually consumed directly or sometimes with salt, lemon juice and powdered chilli. In Indonesia, bengkoang roots have been traditionally used as a cosmetics material for centuries empirically. They have been used as skin whitening materials. Yet, the active compounds in bengkoang roots having skin whitening activity have not previously been investigated (Lukitaningsih, 2009).

Skin whitening compounds are in a close relationship with melanin, the major pigment for colour of skin, hair and eye (Briganti et al., 2003). The production of melanin depends on UV light or sun exposure. It is a natural protective mechanism of the skin against too much UV light penetrating the human skin. Too much UV irradiation causes sunburn, disrupts the synthesis of precursors necessary for DNA synthesis and increases the amount of free radicals. Melanin captures free radicals and participates in other oxidation-reduction processes in the human body (Bleehen et al., 1995).
Melanin is classified into two main groups: the black and brown eumelanins which are insoluble in water and the yellow and reddish-brown phaeomelanin which is alkali soluble. Both melanins were derived from tyrosine by the same initial step, namely oxidation process at the phenolic system (Bleehen et al., 1995; Parvez et al., 2007; Kobayashi et al., 1994); is starting from the conversion of the L-tyrosine to L-3,4dihydroxyphenylalanine (L-DOPA) and followed by the subsequent oxidation of $L$ DOPA to produce an ortho-quinone (dopaquinone) by tyrosinase. Dopaquinone is further transformed via several reactions to yield brown to black melanin which is responsible for the colour of mammal's skin (Okombi et al., 2006; Lee 2002; Ohguchi et al., 2003; Wang and Hebert, 2006). Another two melanogenic enzymes, tyrosine-related protein1 (TRP1) and tyrosine-related protein2 (TRP2), also named dopachrome tautomerase (DCT) (Solano et al., 1994), are involved in the melanin biosynthesis (Kobayashi et al., 1994; Parvez et al., 2007).

Another strategy for maintaining skin whiteness is to avoid ultraviolet exposure. UV 
radiation can also induce the formation of various radicals (Matsuura et al., 2006), primarily reactive oxygen species (ROS) in the skin such as singlet oxygen and superoxide anion, promoting biological damage in exposed tissues via iron-catalyzed oxidative reactions. These radicals play important roles in the activation of tyrosinase in human skin and therefore enhance melanin biosynthesis via induction of the proliferation of the melanocytes. The radicals also cause the damage of DNA. Furthermore, ROS scavengers or inhibitors, such as antioxidant, may reduce hyperpigmentation and can also be used as whitening materials (Wang et al., 2006). Therefore, it is necessary to combine sun screen compounds and antioxidant compounds in cosmetic products to obtain an optimal whitening effect.

\section{MATERIALS AND METHODS Chemicals and solvent}

The chemicals used in the detection and isolation methods were mushroom tyrosinase 4187IU/mg, L-DOPA (dihydroxy phenyl alanine), kojic acid (Fluka, Seelze, Germany), dimethylsulfoxide extra pure $\left(\operatorname{Acros}^{\circledR}\right.$ organic, Geel, Belgium), DPPH (1,1-diphenyl-1picrylhydrazine), catechin, Dulbeco's phosphate buffered saline, (purchased from Sigma Aldrich, Steinheim Germany), ascorbic acid (Sigma Aldrich, Steinheim, Germany), Sephadex LH20 (Aldrich, Steinheim, Germany), Silica gel 60 (particle sizes $0.063-0.200 \mathrm{~mm}$, Merck, Darmstadt, Germany), TLC Aluminium sheets, silica gel 60 F254 (layer thickness $0.2 \mathrm{~mm}$, Merck, Darmstadt, Germany).

Solvents for separation were petroleum ether, ethyl acetate (Fisher Scientific, Leichestershire, UK), methanol (Merck, Darmstadt, Germany), chloroform, dichloromethane and n-butanol (Fluka, Seelze, Germany).

\section{Equipments}

Melting point SMP3 Stuart $^{\circledR}$ apparatus (Staffordshire, UK), Cary 50 Bio UV-Visible spectrophotometer (Varian, California, USA), JASCO FT/IR-6100 Spectrometer (GrossUmstadt, Germany), Thermo Mixer Comfort 5355 V.2.12 Eppendorf (Hamburg, Germany), ALPHA II-12 Freeze dryer (Osterode, Germany), Bruker Avance 400 NMR spectro- meter (Rheinstetten, Germany), Shimadzu GC/MS-QP 20105 gas chromatography (Kyoto, Japan), Agilent 1100 series HPLC apparatus (California, USA) equipped by column Zorbax SB-C18 $(25 \mathrm{~cm}$, i.d. $0.46 \mathrm{~cm}$, $5 \mu \mathrm{m}$, Agilent, California, USA), UV absorbance detector and ESI-MS detectors, Agilent 1100 series preparative-HPLC (California, USA) equipped by column Zorbax SB-C18 $(7 \mu \mathrm{m}$, 21.2X150 mm, Agilent, California, USA).

\section{Plant material and extraction}

Bengkoang was collected from Purworejo, Central Java, Indonesia on the dry season from July until September on 2007. The roots $(45 \mathrm{~kg})$ were peeled and washed with water, subsequently dried at $60^{\circ} \mathrm{C}$ and milled into fine powder. The fine powder $(4.75 \mathrm{~kg})$ was extracted by Soxhlet using 6L petroleum ether. The residue was extracted using methanol to achieve the semi polar and polar compounds. The extracts were filtered and concentrated in vacuum evaporator. The concentrated methanol extract was added with water and then partitioned with ethyl acetate. The ethyl acetate phase was further concentrated.

\section{Compound isolation of ethyl acetate extract}

The ethyl acetate extract (31.1gram) was subjected to silica gel column chromatography and eluted using the gradient mixture of petroleum ether-ethyl acetate and ethyl acetatemethanol producing 35 fractions with $100 \mathrm{~mL}$ of eluents.

Fractions 6-11 which had an $\mathrm{R}_{\mathrm{f}}$ value of 0.17 (positive with DPPH) were collected and evaporated. The fractions may contain antioxidant compounds because the spot was able to reduce DPPH. The concentrated fraction was then purified using column sephadex LH-20 chromatography and methanol as an eluent, producing 50 fractions. Fractions 9-15 were further subjected into preparative HPLC and yield $670 \mathrm{mg}$ yellow crystal (1) that is identified as 8,9-Furanylpterocarpan-3-ol. Fractions 37-40 from column chromatography with an $\mathrm{Rf}$ value of 0.35 on TLC were collected and purified using sephadex column chromatography giving 19 fractions. Fractions 7-11 of this chromatography had the $\mathrm{Rf}$ value of 0.85 
(positive with DPPH) then purified using preparative-HPLC giving $33 \mathrm{mg}$ of compound 2. Based on the GC/MS and NMR spectroscopic data, compound $\mathbf{2}$ was identified as Daidzein.

Fractions 17-24 of the first column chromatography with an $\mathrm{Rf}$ value of 0.52 on TLC were collected and evaporated. The concentrated fraction was purified by preparative HPLC giving two compounds. The compound with a retention time of $11.4 \mathrm{~min}$ (compound 3) was assigned to Daidzein-7O-B-glucopyranose, while the other compound having a retention time of $12.6 \mathrm{~min}$ was assigned to 5-hydroxy-daidzein-7-O-Bglucopyranose (compound 4).

\section{Identification of isolated compounds} New compound 1 (8,9-Furanyl-pterocarpan3-ol)

Yellow crystal; UV MeOH $\lambda_{\max } 293 \mathrm{~nm}$; MW 280; IR $\left(\mathrm{cm}^{-1}\right)$ : 3295, 1624, 1607, 1540, 1494, 1469, 1353, 1306, 1270, 1229, 1144, 1123, 1055, 1018, 960, 843, 826, 764; ESI-MS m/z (\% intensity): $281.3\left([\mathrm{M}+\mathrm{H}]^{+}, 100\right), 123.1$ $\left(\left[\mathrm{C}_{7} \mathrm{H}_{7} \mathrm{O}_{2}\right]^{+}, 100\right), 121.0\left(\left[\mathrm{C}_{7} \mathrm{H}_{7} \mathrm{O}_{2}\right]-100\right) ;{ }^{1} \mathrm{H}$ NMR $\left(500 \mathrm{MHz}, \mathrm{MeOH}-\mathrm{d}_{4}\right): \delta 3.44(\mathrm{dd}, 1 \mathrm{H}$, $\left.\mathrm{H}^{6 \mathrm{a}}\right), 3.48\left(\mathrm{~d}, 1 \mathrm{H}, \mathrm{H}^{\circ}\right), 4,14\left(\mathrm{~d}, 1 \mathrm{H}, \mathrm{H}^{\circ}\right), 5.49$ (d, $\left.1 \mathrm{H}, \mathrm{H}^{11 \mathrm{a}}\right), 6.17\left(\mathrm{~d}, 1 \mathrm{H}, \mathrm{H}^{4}\right), 6.22\left(\mathrm{dd}, 1 \mathrm{H}, \mathrm{H}^{2}\right)$, $6.66\left(\mathrm{~d}, 1 \mathrm{H}, \mathrm{H}^{3}\right), 6.89\left(\mathrm{~s}, 1 \mathrm{H}, \mathrm{H}^{10}\right), 6.95(\mathrm{~d}, 1 \mathrm{H}$, $\left.\mathrm{H}^{1}\right), 7.53\left(\mathrm{~d}, 1 \mathrm{H}, \mathrm{H}^{2}\right), 7.57$ (s, $\left.1 \mathrm{H}, \mathrm{H}^{7}\right) ;{ }^{13} \mathrm{C}$ NMR (125 MHz, MeOH-d 4 ): $\delta 124.66\left(\mathrm{C}^{1}\right)$, $107.40\left(\mathrm{C}^{2}\right), 160.53\left(\mathrm{C}^{3}\right), 97.35\left(\mathrm{C}^{4}\right), 158.45$ $\left(\mathrm{C}^{4 a}\right), 66.84\left(\mathrm{C}^{6}\right), 39.73\left(\mathrm{C}^{6 \mathrm{a}}\right), 116.90\left(\mathrm{C}^{6 \mathrm{~b}}\right)$, $122.89\left(\mathrm{C}^{7}\right), 122.19\left(\mathrm{C}^{8}\right), 155.61\left(\mathrm{C}^{9}\right), 98.87$ $\left(\mathrm{C}^{10}\right), 153.61\left(\mathrm{C}^{10 \mathrm{a}}\right), 79.02\left(\mathrm{C}^{11 \mathrm{a}}\right), 118.03\left(\mathrm{C}^{11 \mathrm{~b}}\right)$, $145.07\left(\mathrm{C}^{2}\right), 105\left(\mathrm{C}^{3}\right)$

DEPT data shows that compound 1 has 17 carbons that divided into 3 groups: $9(-\mathrm{CH})$, $1\left(-\mathrm{CH}_{2}\right)$ and 7 quaternary carbons (C). COSY data shows the correlation of $\mathrm{H}^{3}{ }^{3}-\mathrm{H}^{2}$ and $\mathrm{H}^{2-}$ $\mathrm{H}^{1}$. HMBC data shows the signal from the correlation between $\mathrm{C}^{2}$ to $\mathrm{H}^{4}$.

\section{Compound 2 (Daidzein)}

Brown powder; m.p. 295-297 ${ }^{\circ} \mathrm{C}$; MW 254; IR (cm-1): 3149, 1621, 1592, 1573, 1514, 1456, 1381, 1307, 1234, 1190, 1094, 1044, 838, 769, 774; EIMS m/z (\% intensity): 254 ([M] ${ }^{+}$, 100), 226 (47.2), 197 (7.2), $137\left(\left[\mathrm{C}_{7} \mathrm{H}_{6} \mathrm{O}_{3}\right]^{+}\right.$, 100), $118\left(\left[\mathrm{C}_{8} \mathrm{H}_{6} \mathrm{O}\right]^{+}\right.$, 75.1), 108 (32.6), 89 (45.4), 80 (20.5), 63 (35.0), 51 (29.2), 39 (23.7);
${ }^{1} \mathrm{H}$ NMR (500 MHz, MeOH-d 4 ): $\delta 6.74(\mathrm{~s}, 1 \mathrm{H}$, $\left.\mathrm{H}^{8}\right), 6.76\left(\mathrm{~d}, 2 \mathrm{H}, \mathrm{H}^{3}, \mathrm{H}^{5}\right), 6.85\left(\mathrm{~d}, 1 \mathrm{H}, \mathrm{H}^{6}\right), 7.26$ (d, $\left.2 \mathrm{H}, \mathrm{H}^{2}, \mathrm{H}^{6}\right), 7.95$ (d, $\left.1 \mathrm{H}, \mathrm{H}^{5}\right), 8.02(\mathrm{~s}, 1 \mathrm{H}$, $\left.\mathrm{H}^{2}\right) ;{ }^{13} \mathrm{C}$ NMR $\left(125 \mathrm{MHz}, \mathrm{MeOH}_{-} \mathrm{d}_{4}\right): \delta 153.04$ $\left(C^{2}\right), 124.32\left(C^{3}\right), 176.57\left(C^{4}\right), 128.53\left(C^{5}\right)$, $116.47\left(\mathrm{C}^{6}\right), 164.62\left(\mathrm{C}^{7}\right), 103.24\left(\mathrm{C}^{8}\right), 158.72$ $\left(\mathrm{C}^{9}\right), 118.23\left(\mathrm{C}^{10}\right), 125.98\left(\mathrm{C}^{1}\right), 131,24\left(\mathrm{C}^{2}\right)$, $116.24\left(\mathrm{C}^{3}\right), 159.82\left(\mathrm{C}^{4}\right), 116.24\left(\mathrm{C}^{5}\right), 131.42$ $\left(\mathrm{C}^{6}\right)$.

COSY data shows the correlations of $\mathrm{H}^{6}-\mathrm{H}^{5} ; \mathrm{H}^{2}-^{3}$ and $\mathrm{H}^{6}-\mathrm{H}^{5}$. HMBC data shows the correlations between $\mathrm{H}^{2}$ and $\mathrm{C}^{1}{ }^{1}\left(3 \int_{C-H}\right), \mathrm{H}^{2}$ and $\mathrm{C}^{4}\left(3_{C-H}\right), \mathrm{H}^{2}$ and $\mathrm{C}^{9}\left(3^{3} \mathrm{C}_{-H}\right), \mathrm{H}^{5}$ and $\mathrm{C}^{7}\left({ }^{3} \mathrm{~J}_{\mathrm{C}}\right.$ $H), \mathrm{H}^{2}$ and $\mathrm{C}^{1}\left({ }^{2} J_{C-H}\right)$, and $\mathrm{H}^{6}$ and $\mathrm{C}^{1}\left({ }^{2} J_{C-H}\right)$.

Compound 3 (Daidzein-7-O-B-glucopyranose) Yellow powder; MW 416; UV $(\mathrm{MeOH})$ $\lambda_{\max } 260 \mathrm{~nm}$; IR $\left(\mathrm{cm}^{-1}\right): 3324,2921,1617,1516$, 1445, 1374, 1249, 1070, 1044, 887, 836, 785; ESI-MS $\mathrm{m} / \mathrm{z}$ (\% intensity): $417\left([\mathrm{M}+\mathrm{H}]^{+}, 100\right)$, $255\left(\left[\mathrm{M}-\mathrm{C}_{6} \mathrm{H}_{11} \mathrm{O}_{6}\right]^{+}, 100\right) ;{ }^{1} \mathrm{H}$ NMR $(500 \mathrm{MHz}$, $\left.\mathrm{MeOH}-\mathrm{d}_{4}\right): \delta 6.78\left(\mathrm{~d}, 2 \mathrm{H}, \mathrm{H}^{3}, \mathrm{H}^{5}\right), 7.12(\mathrm{~d}$, $\left.1 \mathrm{H}, \mathrm{H}^{\circ}\right), 7.16\left(\mathrm{~s}, 1 \mathrm{H}, \mathrm{H}^{8}\right), 7.29$ (d, $2 \mathrm{H}^{2} \mathrm{H}^{2}, \mathrm{H}^{6}$ ), $8.06\left(\mathrm{~d}, 1 \mathrm{H}, \mathrm{H}^{5}\right), 8.11\left(\mathrm{~s}, 1 \mathrm{H}, \mathrm{H}^{2}\right), 5.03(\mathrm{~d}, 1 \mathrm{H}$, $\mathrm{H}^{1 "}$ ), 3.36-3.86 (m, 6H, H $\mathrm{H}^{2 \prime}, \mathrm{H}^{3 “}, \mathrm{H}^{4^{\prime \prime}}, \mathrm{H}^{5^{\prime \prime}}, \mathrm{H}^{6^{\prime \prime}}$ ); ${ }^{13} \mathrm{C}$ NMR (125 MHz, MeOH-d 4 ): $\delta 154.04\left(\mathrm{C}^{2}\right)$, $124.87\left(\mathrm{C}^{3}\right), 177.09\left(\mathrm{C}^{4}\right), 127.14\left(\mathrm{C}^{5}\right), 115.89$ $\left(\mathrm{C}^{6}\right), 162.13\left(\mathrm{C}^{7}\right), 103.79\left(\mathrm{C}^{8}\right), 157.97 \quad\left(\mathrm{C}^{9}\right)$, $118.94\left(\mathrm{C}^{10}\right), 124.87\left(\mathrm{C}^{1}\right), 130,23\left(\mathrm{C}^{2}\right), 115.15$ $\left(C^{3}\right), 157.19\left(C^{4}\right), 115.15\left(C^{5}\right), 130.23\left(C^{6}\right)$, $100.42\left(\mathrm{C}^{1 *}\right), 73.41\left(\mathrm{C}^{2 \times}\right), 76.42\left(\mathrm{C}^{3 *}\right), 69.93$ $\left(\mathrm{C}^{4}\right), 77.00\left(\mathrm{C}^{5^{\circ}}\right), 61.10\left(\mathrm{C}^{6}\right)$.

COSY data shows correlations between the protons of $\mathrm{H}^{5}-6^{\mathrm{H}}, \mathrm{H}^{2}-\mathrm{H}^{3}$ and $\mathrm{H}^{5}-\mathrm{H}^{6}$. HMBC data shows the correlations of $\mathrm{H}^{1 \text { "'- }} \mathrm{C}^{7}$, $\mathrm{H}^{3}-\mathrm{C}^{1}\left({ }^{3} J_{C-H}\right), \mathrm{H}^{6}-\mathrm{C}^{9}\left({ }^{4} J_{C-H}\right), \mathrm{H}^{2}-\mathrm{C}^{1}\left({ }^{3} J_{C-H}\right), \mathrm{H}^{2-}$ $\mathrm{C}^{9}\left(3^{3} \mathrm{C}_{-H}\right)$ and $\mathrm{H}^{2}-\mathrm{C}^{4}\left(3_{C-H}\right)$.

\section{Compound 4 (5-Hydroxy-daidzein-7-O-ß-} glucopyranose)

Yellow-brown powder; MW 432; UV $(\mathrm{MeOH}) \lambda_{\max } 260 \mathrm{~nm}$; IR $\left(\mathrm{cm}^{-1}\right): 3330,2927$, 1651, 1614, 1516, 1444, 1363, 1251, 1177, 1069, 1044, 837, 789; ESI-MS m/z (\% intensity): $433.2\left([\mathrm{M}+\mathrm{H}]^{+}, 100\right), 271\left(\left[\mathrm{M}-\mathrm{C}_{6} \mathrm{H}_{11} \mathrm{O}_{6}\right]^{+}, 100\right)$; ${ }^{1} \mathrm{H}$ NMR (500 MHz, MeOH-d $): \delta 6.76(\mathrm{~d}, 2 \mathrm{H}$, $\left.\mathrm{H}^{3}, \mathrm{H}^{5}\right), 6.58\left(\mathrm{~d}, 1 \mathrm{H}, \mathrm{H}^{\circ}\right), 6.39\left(\mathrm{~s}, 1 \mathrm{H}, \mathrm{H}^{8}\right), 7.29$ (d, $\left.2 \mathrm{H}, \mathrm{H}^{2}, \mathrm{H}^{6}\right), 8.03\left(\mathrm{~d}, 1 \mathrm{H}, \mathrm{H}^{2}\right), 4.95(\mathrm{~d}, 1 \mathrm{H}$,

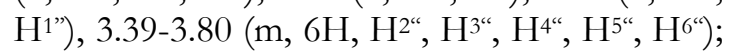
${ }^{13} \mathrm{C}$ NMR (125 MHz, MeOH-d 4$): \delta 156.32\left(\mathrm{C}^{2}\right)$, $84.32\left(C^{3}\right), 174.21\left(C^{4}\right), 164.77\left(C^{5}\right), 101.64\left(C^{6}\right)$, 
$163.07\left(\mathrm{C}^{7}\right), 94.00\left(\mathrm{C}^{8}\right), 157.68\left(\mathrm{C}^{9}\right), 115.08$ $\left(\mathrm{C}^{10}\right), 127.93\left(\mathrm{C}^{1}\right), 130,16\left(\mathrm{C}^{2}\right), 115.08\left(\mathrm{C}^{3}\right)$, $157.69\left(\mathrm{C}^{4}\right), 115.08\left(\mathrm{C}^{5}\right), 130.16\left(\mathrm{C}^{6}\right), 100.41$ $\left(\mathrm{C}^{14}\right), 73.48\left(\mathrm{C}^{24}\right), 76.61\left(\mathrm{C}^{34}\right), 69.98\left(\mathrm{C}^{4}\right), 77.15$ $\left(\mathrm{C}^{54}\right), 62.43\left(\mathrm{C}^{6 /}\right)$

COSY data show the correlations of $\mathrm{H}^{2}$ $\mathrm{H}^{3}$ and $\mathrm{H}^{5}-\mathrm{H}^{6}$. HMBC data shows the correlations of $\mathrm{H}^{2}-\mathrm{C}^{1}\left({ }^{3} J_{C-H}\right), \mathrm{H}^{2}-\mathrm{C}^{4}\left({ }^{3} J_{C-H}\right), \mathrm{H}^{2}-$ $\mathrm{C}^{9}\left(3_{C-H}\right)$ and $\mathrm{H}^{1}{ }^{\prime}-\mathrm{C}^{7}\left(3_{C-H}\right)$.

\section{Assay of antioxidant and tyrosinase activity Assay of antioxidant activity}

The antioxidant activity of crude extracts and isolated compounds were evaluated by measuring the scavenging activity assay against DPPH radical with ascorbic acid as the positive control (IC50 $7.24 \mathrm{ppm}$ ) according to Wang et al., (2006) and Dickson et al., (2007). 4mL of $100 \mu \mathrm{M}$ 1,1-diphenyl-2-picrylhydrazyl (DPPH) solution in methanol was thoroughly mixed with $1 \mathrm{~mL}$ of a sample solution at various concentrations. The mixture was kept in the dark for $30 \mathrm{~min}$. The absorbance of these solutions was measured at $517 \mathrm{~nm}$. The concentration in ppm at which the absorbance decreased to $50 \%$ of its initial value was used as the $\mathrm{SC}_{50}$ value for each test solution. All tests were done in triplicate.

\section{Assay of tyrosinase inhibition}

Tyrosinase inhibitory activity of crude extracts and isolated compounds was measured according to Hearing (1987) and Rangkadilok et al. (2006) with a slight modification using mushroom tyrosinase as the enzyme, L-DOPA as the substrate and kojic acid as the positive control. An aliquot $(50 \mu \mathrm{L})$ of samples in DMSO was mixed with $100 \mu \mathrm{L}$ of $200 \mathrm{IU} / \mathrm{mL}$ of mushroom tyrosinase and $100 \mu \mathrm{L}$ of phosphate buffered saline ( $\mathrm{pH}$ 6.8). The assay mixture was pre-incubated at $37^{\circ} \mathrm{C}$ for $10 \mathrm{~min}$ and then $100 \mu \mathrm{L}$ of $L-1,4$-dihydroxyphenylalanine (L-DOPA) solution $7.6 \mathrm{mM}$ was added. This reaction mixture incubated for $15 \mathrm{~min}$ at $37^{\circ} \mathrm{C}$. The dopachrome was measured at $475 \mathrm{~nm}$ using a UV/Vis spectrophotometer (A). As a blank, DMSO was used (B). As a colour control test, phosphate buffer was used instead of the enzyme tyrosinase $(C)$. The percentage of tyrosinase inhibitions was expressed as a percentage of inhibition of tyrosinase activity and calculated as follows:

Tyrosinase inhibition (\%): $\frac{\{\mathrm{B}-(\mathrm{A}-\mathrm{C})\}}{\mathrm{B}} \times 100 \%$

Kojic acid was used as a standard inhibitor for tyrosinase. All tests were done in triplicate.

\section{RESULTS AND DISCUSSION}

In order to isolate active compounds of the extracts, a bioassay-guided fractionation has been performed with a column chromatography and TLC using DPPH reagent for antioxidant detector. Equal fractions with the same Rf on TLC showing the antioxidant activity were collected and further analyzed using mushroom tyrosinase to evaluate their tyrosinase inhibitory activity. Compounds having both antioxidant and tyrosinase inhibitory activities, can be developed as skin whitening compounds in cosmetics. Compounds 1, 2, 3 and 4 are candidates for the skin whitening compound.

The chemical structures of isolated compounds can be found in Figure 1. New compound 1 was isolated from the ethyl acetate extract as yellow crystals. The UV spectrum shows that the compound 1 has a high activity to absorb the UV light at a maximum wavelength $293 \mathrm{~nm}$, therefore it is predicted that compound $\mathbf{1}$ has many conjugated C-C bounds. This compound has also the potential to reduce the DPPH reagent and exhibits antioxidant activity and tyrosinase inhibitory activity. Therefore, the structure was carefully elucidated. The molecular formula of compound 1, $\mathrm{C}_{17} \mathrm{H}_{12} \mathrm{O}_{4}$ is determined by ESI$\mathrm{LC} / \mathrm{MS} \mathrm{m} / \mathrm{z}[\mathrm{M}+\mathrm{H}]^{+}$281.3. In addition, MS spectra show that the compound $\mathbf{1}$ is fragmented producing signal $\mathrm{m} / \mathrm{z}$ at 123 (in positive detection) and $\mathrm{m} / \mathrm{z}$ at 121 (in negative detection). Its ${ }^{1} \mathrm{H}$ NMR spectrum exhibits five aromatic protons at $\delta_{\mathrm{H}} 7.6\left(\mathrm{~s}, \mathrm{H}^{7}\right), 6.9(\mathrm{~d}$, $\left.\mathrm{J}=8.06 \mathrm{~Hz} ; \mathrm{H}^{1}\right), 6.9$ (s, H$\left.{ }^{10}\right), 6.2$ (dd, J=8.06; $\left.2.20 ; \mathrm{H}^{2}\right), 6.2\left(\mathrm{~d}, \mathrm{~J}=2.23, \mathrm{H}^{4}\right)$. There are a coupling of meta-related protons $\left(\mathrm{H}^{2}-\mathrm{H}^{4}\right)$ and a coupling of ortho-related protons $\left(\mathrm{H}^{1}-\mathrm{H}^{2}\right)$.

The signals at $\delta_{\mathrm{H}} 7.5\left(\mathrm{~d}, \mathrm{~J}=2.25, \mathrm{H}^{2}\right)$ and $6.7(\mathrm{~d}$, $\left.\mathrm{J}=2.23, \mathrm{H}^{3}\right)$ are characteristic for orthorelated protons in a furan system. The finding was also supported by the correlation of $\delta 7.5\left(\mathrm{H}^{2}\right)$ and $\delta 6.7\left(\mathrm{H}^{3}\right)$ in the COSY diagram. 
<smiles>Oc1ccc2c(c1)OCC1c3cc4ccoc4cc3OC21</smiles>

Compound 1

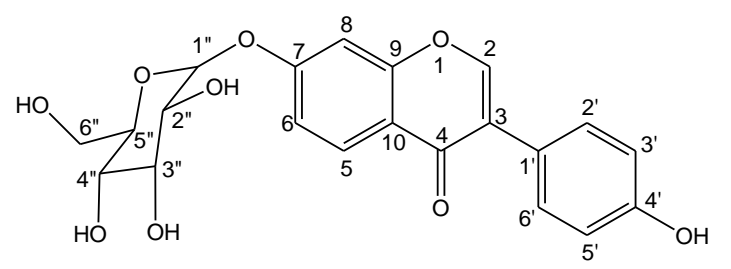

Compound 3<smiles>Cc1oc2cc(O)ccc2c(=O)c1-c1ccc(O)cc1</smiles>

Compound 2<smiles>[14CH3]Oc1cc(O)c2c(=O)c(-c3ccc(O)cc3)coc2c1</smiles>

Compound 4

Figure 1. Chemical structure of isolated compounds in ethyl acetate extract of Bengkoang

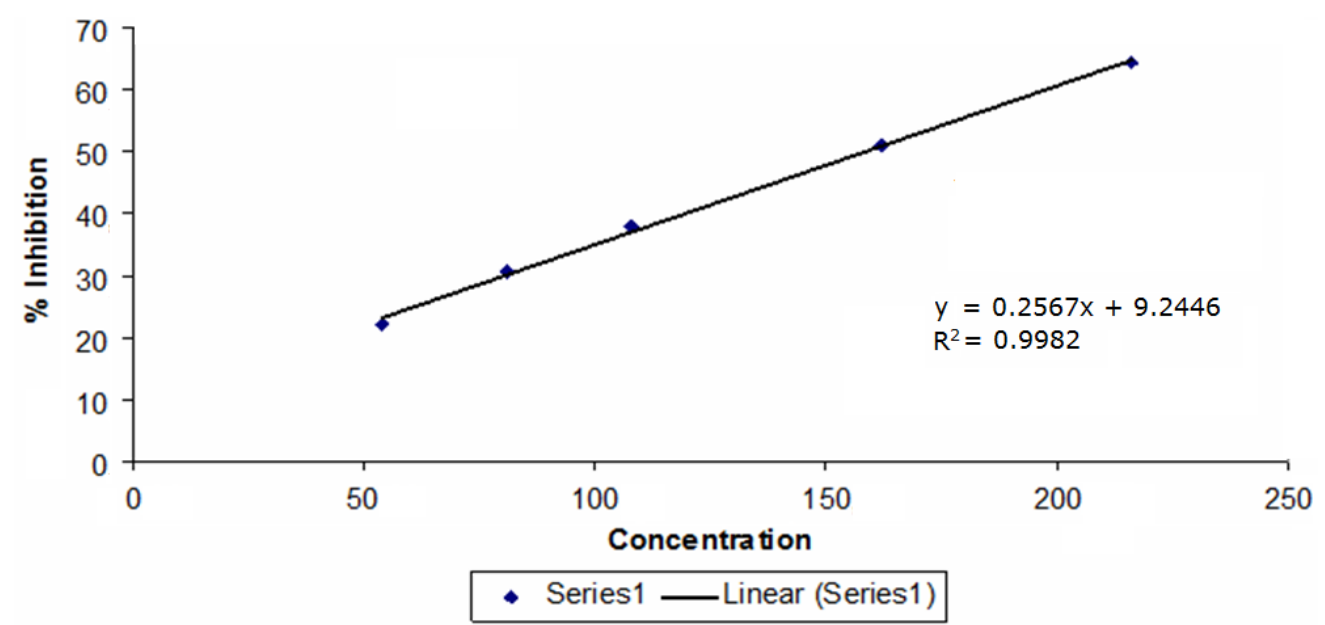

Figure 2. Concentration-tyrosinase inhibition (\%) curve of Bengkoang crude extracts

Four protons appeared at $\delta_{\mathrm{H}} 4.1(\mathrm{~d}, \mathrm{~J}=9.68$, $\mathrm{H}^{\circ}$ ), 3.5 (d, J=10.30, $\mathrm{H}^{\circ}$ ), 3.4 (dd, J=5.63; 2.85, $\left.\mathrm{H}^{6 \mathrm{a}}\right), 5.5\left(\mathrm{~d}, \mathrm{~J}=6.71, \mathrm{H}^{11 \mathrm{a}}\right)$ are characteristic for $-\mathrm{O}-\mathrm{CH}_{2}-\mathrm{CH}-\mathrm{CH}-\mathrm{O}$. This fact was also supported by ${ }^{13} \mathrm{C}$ NMR spectra. From the DEPT spectrum, we know that the compound 1 has 17 carbons that divided into 3 groups: 9 ($\mathrm{CH}), 1\left(-\mathrm{CH}_{2}\right)$ and 7 quaternary carbons $(\mathrm{C})$. The presence of hydroxyl group is indicated by band at $3295 \mathrm{~cm}^{-1}$ in IR spectrum. In addition, the IR spectrum shows main bands at 1607 , $1469,1493 \mathrm{~cm}^{-1}\left(-\mathrm{C}=\mathrm{C}\right.$ - aromatic) and $1084 \mathrm{~cm}^{-1}$ (-C-O-C-). Based on the NMR assignments, IR spectrum and the fragmentation pattern above, compound $\mathbf{1}$ is identified as 8,9-furanylpterocarpan-3-ol.

Compounds 2, 3 and 4 were obtained from the ethyl acetate extract and identified by spectral data as isoflavonoid groups. The ${ }^{1} \mathrm{H}$ NMR spectra of the compounds 2, 3 and 4 show the signals in aromatic region with the pattern typical for isoflavonoids. In addition, the HMBC diagrams of these compounds reveal significant correlations between $\mathrm{H}^{2}$ and $\mathrm{C}^{1}\left({ }^{3} \mathrm{~J}_{\mathrm{CH}}\right), \mathrm{H}^{2}$ and $\mathrm{C}^{4}$ $\left({ }^{3} J_{C-H}\right), \mathrm{H}^{2}$ and $\mathrm{C}^{9}\left({ }^{3} J_{C-H}\right)$ that confirm the presence of the isoflavone skeleton. This finding is in accordance with Falco et al., (2005). 
Table I. The $\mathrm{SC}_{50}$ of antioxidant activity of crude extract and isolated compounds

\begin{tabular}{cc}
\hline Name & SC $_{50}$ value (Mean \pm SD) \\
\hline Standard & $0.041 \pm 0.001 \mathrm{mM}$ \\
Ascorbic acid & $175.06 \pm 3.28 \mathrm{ppm}$ \\
Extract & \\
Ethyl acetate & $2.113 \pm 0.001 \mathrm{mM}$ \\
Isolated compounds & $11.86 \pm 0.23 \mathrm{mM}$ \\
Compound 1 & $0.697 \pm 0.002 \mathrm{mM}$ \\
Compound 2 & $7.857 \pm 0.069 \mathrm{mM}$ \\
Compound 3 & \\
Compound 4
\end{tabular}

Table II. The $\mathrm{IC}_{50}$ of tyrosinase inhibitory activity of crude extract and isolated compounds

\begin{tabular}{cc}
\hline Name & IC $_{50}$ value \\
\hline Standard & \\
Kojic acid standard & $0.070 \pm 0.001 \mathrm{mM}$ \\
Extract & \\
Ethyl acetate & $158.13 \pm 1.36 \mathrm{ppm}$ \\
Isolated compounds & $7.19 \pm 0.11 \mathrm{mM}$ \\
Compound 1 & $5.35 \pm 0.03 \mathrm{mM}$ \\
Compound 2 & $22.20 \pm 0.27 \mathrm{mM}$ \\
Compound 3 & $4.38 \pm 0.01 \mathrm{mM}$ \\
Compound 4 & \\
\hline
\end{tabular}

The NMR and mass spectra of compound 2 are in accordance with daidzein data reported by Shimoda et al., (2008), Santos et al., (2006) and Setchell and Welsh (1987). The ${ }^{1} \mathrm{H}$ NMR spectrum of compound 3 shows that the chemical shift values of the proton $\mathrm{H}^{6}$ and $\mathrm{H}^{8}$ are relatively upfield and it supports that the substituent attached of $\mathrm{C} 7$ is not a hydroxyl group but a $\beta$-glucopyranose. The presence of $\beta$-glucopyranose is supported by a $\beta$-anomeric proton signal at $\delta 5.03 \mathrm{ppm}(1 \mathrm{H}, \mathrm{d}, \mathrm{J}=7.4$ and $\delta_{\mathrm{C}}$ of $100.42 \mathrm{ppm}$ and also by the other group signals at $\delta 3.38-3.86 \mathrm{ppm}$. This finding is in accordance with Shimoda et al., (2008). The compound $\mathbf{3}$ is identified as daidzein-7-O-Bglucopyranose. The ${ }^{1} \mathrm{H}$ and ${ }^{13} \mathrm{C}$ NMR of compound $\mathbf{4}$ are different from the signal of $\mathbf{3}$ without hydroxyl at position $C^{5}$. The chemical shift value of $\mathrm{H}^{6}$ in molecule 4 was relatively downfield because of the presence of $-\mathrm{OH}$ at $C^{5}$. The NMR spectra of 4 are in accordance with the data of a hydroxylated daidzein reported by Murthy et al., (1986) and Shimoda et al., (2008). Thus, the compound 4 is elucidated as 5-hydroxy-daidzein-7-O-ß-glucopyranose.

\section{Antioxidant activity assay}

The antioxidant activity of the crude extracts and some of the isolated compounds were evaluated by means of scavenging activity assay using DPPH radical and ascorbic acid as a positive control ( $\mathrm{IC}_{50} 7.24 \mathrm{ppm}$ or $0.04 \mathrm{mM}$ ). The corresponding $\mathrm{SC}_{50}$ value can be seen in the table I.

The scavenging activity of the ethyl acetate extract was 175.06 \pm 3.28 . The isoflavonoid compounds, daidzein and daidzein-7-O-ß-glucopyranose contain phenol groups which are responsible to their antioxidant activity. According to Jayaprakasha et al., (2003), the antioxidant activity of some natural products depends on the presence of polyphenols which may act as reductors.

\section{Tyrosinase Inhibition Assay}

The catalytic action of tyrosinase enzyme was the conversion of tyrosine with oxygen to give DOPA which was then converted to dopaquinone and water. Subsequently, dopaquinone was converted through autooxidation to dopachrome, an orange to red 
pigment with the value of maximum absorbance at $475 \mathrm{~nm}$.

The results provided in figure 2 demonstrate that the ethyl acetate extract shows a significant correlation between the concentration and the tyrosinase inhibitory activity. In cosmetic fields, the ethyl acetate extract can be developed as a natural skinwhitening agent. The $\mathrm{IC}_{50}$ value of crude extracts and the isolated compounds are displayed in table II.

Comparison of the tyrosinase inhibition potency of isoflavonoids reveals that 5hydroxy-daidzein-7-O-ß-glucopyranose has the greatest inhibition activity, followed by daidzein, 8,9-furanyl-pterocarpan-3-ol and daidzein-7-O-ß-glucopyranose, respectively. The decrease of the activities from daidzein to daidzein-7-O-ß-glucopyranose may be caused by the glucopyranosyl substituent providing steric bulk. The result is in accordance with findings reported by Chang (2007). The active site of enzyme tyrosinase consisted of two copper atoms that are each coordinated with three histidine residue (Mirica et al., 2005). The compounds having phenol or diphenol group can form a chelate complex with copper in the enzyme and thus irreversibly inactivate the tyrosinase. Daidzein-7-O-B-glucopyranose has only one phenol group because the other phenol groups bond to a glucose molecule which forms a weak complex resulting in a lower inhibitory activity.

The compound of 5-hydroxy-daidzein-7O-B-glucopyranose is also a glycoside having an extra hydroxyl group at position $\mathrm{C}^{4}$ beside the $\mathrm{OH}$ group at position $\mathrm{C}^{4}$. However, the tyrosinase inhibition activity is still greater than that of daidzein compound. The hydroxyl group $(-\mathrm{OH})$ at position 4 adjacent to the carbonyl group $(-\mathrm{C}=\mathrm{O})$ enables this compound to form a strong chelation with the copper of the active site enzyme, so that the inhibition power is greater than the aglycon molecule of daidzein. The molecule of 8,9-furanylpterocarpan-3-ol has only one hydroxyl -OH at position $\mathrm{C}^{7}$ and no carbonyl group $(-\mathrm{C}=\mathrm{O})$, thus the activity is much lower than the aglycon daidzein.

\section{CONCLUSION}

Three isolated isoflavonoids (daidzein, daidzein-7-O-ß-glucopyranose; 5-hydroxyldaidzein-7-O-ß-glucopyranose), and (8,9)furanyl-pterocarpan-3-ol showed interesting antioxidant and tyrosinase inhibitory activities. The $\mathrm{SC}_{50}(\mathrm{mM})$ values of isolated compounds were $11.86 \pm 0.23 ; \quad 0.697 \pm 0.002 ; 7.857 \pm 0.069$; $2.113 \pm 0.001$, for daidzein, daidzein-7-O-ßglucopyranose, 5-hydroxy-daidzein-7-O- $3-$ glucopyranose and 8,9-furanyl-pterocarpan-3ol, respectively. In addition, the $\mathrm{IC}_{50}$ values (in $\mathrm{mM}$ ) to inhibit tyrosinase of compounds were $5.35 \pm 0.03 ; 22.20 \pm 0.27 ; 4.39 \pm 0.01 ; 7.18 \pm 0.11$; $0.198 \pm 0.004 ; 1.21 \pm 0.02$, respectively.

\section{ACKNOWLEDGEMENTS}

We are grateful to the Germany Academic Exchange Service (DAAD) for financial support.

\section{REFERENCES}

Bleehen, SS., Ebling, FJG., Champion, RH., 1995, Disorders of skin Colour, Textbook of dermatololgy, Vol.3, Ed.5., 1561-1577

Briganti, S., Camera, E., Picardo, M., 2003, Chemical and instrumental approaches to treat hyperpigmentation, Pigment Cell Res., 16, 101-110

Chang, TS., 2007, Two potent suicide substrate of mushroom tyrosinase: 7,8,4'trihydroxyisoflavone and 5,7,8,4'tetrahydroxyisoflavone, J. Agric. Food Chem., 55, 2010-2015

Dickson, RA., Houghton, PJ., Hylands, PJ., 2007, Antibacterial and antioxidant cassane diterpenoids from Caesalpinia benthamiana, Phytochem., 68, 1436-1441

Falco, MJC., Pouliquem, YBM., Lima, MAS., Gramosa, NV., et al., 2005, Cytotoxic Flavonoids from Platymiscium floribundum, J. Nat. Prod., 68, 423-426

Hearing, VJJr., 1987, In Methods in Ensymology, Academic Press, New York, 142, 154165

Jayaprakasha, GK., Selvi, T., Sakariah, KK., 2003, Antibacterial and Antioxidant Activities of Grape (Vitis vinifera) Seed Extracts, Food Res. Internat., 36, 117-122

Kobayashi, T., Urabe, K., Winder, A., JimenezCervantes, C., et al., 1994,Tyrosinase related Protein 1 (TRP1) functions as a 
DHICA oxidase in melanin biosynthesis, EMBO Journal, 13, 5818-5825

Lee, HS., 2002, Tyrosinase inhibitors of Pulsatilla cernua root-derived materials, J. Agric. Food. Chem., 50, 1400-1403

Lukitaningsih, E., 2009, The Exploration of whitening and sun screening compounds in Bengkoang roots (Pachyrbizus erosus), Dissertation, 1-28

Matsuura, R., Ukeda, H., Sawamura, M., 2006, Tyrosinase inhibitory activity of Citrus essential oils, J. Agric. Food Chem., 54, 2309-2313

Mirica, LM., Vance, M., Rudd, DJ., Hedman, B., Hodgson, KO., Solomon, EI, Stack, TDP., 2005, Tyrosinase reactivity in a model complex: An alternative hydroxylation mechanism, Science, 308, 1890-1892

Murthy, MSR., Rao, EV., Ward, RS., 1986, Carbon-13 Nuclear Magnetic Resonance Spectra of Isoflavones, Magn. Resn. in Chem., 24, 225-230

Ohguchi, K., Tanaka, T., Iliya, I., Ito, T., Iinung, M., et al., 2003, Gnetol as a potent tyrosinase inhibitor from Genus Gnetum, Biosci. Biotechnol. Biochem., 67, 663-665

Okombi, S., Rival, D., Bonnet, S., Mariotte, AM., Perrier, E., Boumendjel, A., 2006, Analogues of N-hydroxycinnamoylphenalkylamides as inhibitors of human melanocyte-tyrosinase, Bioorg. Med. Lett., 16, 2252-2255

Parvez S., Kang M., Chung HS., Bae, H., 2007, Naturally occurring tyrosinase inhibitors: mechanism and applications in skin health, cosmetics and agriculture industrie, Phytother. Res, 21, 805-816
Rangkadilok, N., Sitthimonchai, S., Worasuttayangkurn, L., Mahidol, C., Ruchirawat, M., Satayavivad, J., 2006, Evaluation of free radical scavenging and antityrosinase activities of standardized longan fruit extract, Food Chem. Toxicol., 1016-1024

Santos, LS., Catharino, RR., Aguiar, CL., Tsai, SM., Eberlin, MN., 2006, Chemotaxonomic markers of organic, natural, and genetically modified soybeans detected by direct infusion electrospray ionization mass spectrometry, $J$. Radioanal. Nucl. Chem., 269, 505-509

Setchell, KDR., Welsh, MB., 1987, Highperformance liquid chromatography analysis of phytoestrogens in soy protein prepara-tions with ultraviolet, electrochemical and thermospray mass spectrometric detection, J. Chromatogr., 386, 313-323

Shimoda, K., Sato, N., Kobayashi, T., Hamada, H., Hamada, Hi., 2008, Glycosylation of daidzein by the Eucalyptus cell cultures, Phytochemistry, 69, 2303-2306

Solano, F., Martinez-Liarte, JH., JimenezCervantes, C., Garcia-Borron, JC., Lozano, JA., Dopachrome Tautomerase is a Zinc-containing Enzyme, Biochem. Biophys. Res., Comm., 204, 1994, 12431250

Wang, KH., Lin, RD, Hsu, FL., Huang, YH., Chang, HC., Huang, CY., Lee, MH., 2006, Cosmetic applications of selected traditional Chinese herbal medicines, $J$. Ethnopharmacol., 106, 353-359

Wang, N., Hebert, DN., 2006, Tyrosinase maturation through the mammalian secretory pathway: bringing color to life, Pigment Cell Res. 19, 3-18 